\title{
Correction to: Time to engage: Implementing math and literacy blended learning routines in an Indian elementary classroom
}

\author{
Arnab Kundu ${ }^{1}$ (D) $\cdot$ Tripti Bej $^{2} \cdot$ Mary Rice $^{3}$ \\ Published online: 30 September 2020 \\ C) Springer Science+Business Media, LLC, part of Springer Nature 2020
}

\section{Correction to: Education and Information Technologies https://doi.org/10.1007/s10639-020-10306-0}

After publication of this work, we noted that we failed to include the complete list of all coauthors. The full list of authors is now presented in this article.

The original article has been corrected.

Publisher's note Springer Nature remains neutral with regard to jurisdictional claims in published maps and institutional affiliations.

The online version of the original article can be found at https://doi.org/10.1007/s10639-020-10306-0

Arnab Kundu

arnabkundu5@gmail.com

Tripti Bej

tapubej@gmail.com

Mary Rice

maryrice@unm.edu

1 Department of Education, Bankura University, Bankura, West Bengal 722155, India

2 Srima Balika Vidyalaya, Paschim Medinipore, West Bengal, India

3 University of New Mexico, Albuquerque, NM, USA 